\title{
Front Matter: Volume 11747
}

, "Front Matter: Volume 11747,," Proc. SPIE 11747, Autonomous Air and Ground Sensing Systems for Agricultural Optimization and Phenotyping VI, 1174701 (5 May 2021); doi: 10.1117/12.2598648

SPIE. Event: SPIE Defense + Commercial Sensing, 2021, Online Only 


\title{
Autonomous Air and Ground Sensing Systems for Agric ultural Optimization and Phenotyping VI
}

\author{
J. Alex Thomasson \\ Alfonso F. Torres-Rua \\ Editors
}

12-16 April 2021

Online Only, United States

Sponsored and Published by SPIE 
The papers in this volume were part of the technical conference cited on the cover and title page. Papers were selected and subject to review by the editors and conference program committee. Some conference presentations may not be available for publication. Additional papers and presentation recordings may be a vaila ble online in the SPIE Digital Libra ry at SPIEDigita lLibrary.org.

The papers reflect the work and thoughts of the authors and a re published herein as submitted. The publisher is not responsible for the valid ity of the information or for any outc omes resulting from reliance thereon.

Please use the following format to cite material from these proceedings: Author(s), "Title of Paper," in Autonomous Air and Ground Sensing Systems for Agric ultural Optimization and Phenotyping VI, edited by J. Alex Thomasson, Alfonso F. Torres-Rua, Proc. of SPIE 11747, Seven-digit Artic le CID Number (DD/MM/YYYY); (DOI URL).

ISSN: 0277-786X

ISSN: 1996-756X (electronic)

ISBN: 9781510643314

ISBN: 9781510643321 (electronic)

Published by

SPIE

P.O. Box 10, Bellingham, Wa shington 98227-0010 USA

Telephone +1 3606763290 (Pacific Time)

SPIE.org

Copyright @ 2021 Society of Photo-Optic al Instrumentation Engineers (SPIE).

Copying of material in this book for intemal or personal use, or for the intemal or personal use of specific clients, beyond the fair use provisions granted by the U.S. Copyright Law is authorized by SPIE subject to payment of fees. To obta in permission to use and share articles in this volume, visit Copyright Clearance Center at copyright.com. Other copying for republication, resale, a dvertising or promotion, or any form of systematic or multiple reproduction of any material in this book is prohibited except with pemission in writing from the publisher.

Printed in the United States of Americ a by Curran Associates, Inc., under license from SPIE.

Publication of record for individual papers is online in the SPIE Digital Libra ry.

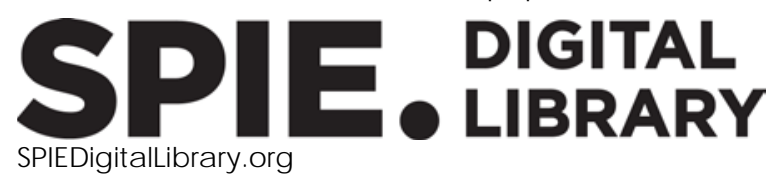

\footnotetext{
Paper Numbering: A unique c itation identifier (CID) number is assigned to each article in the Proceedings of SPIE at the time of public ation. Utilization of CIDs allows artic les to be fully citable as soon as they are published online, and connects the same identifier to all online and print versions of the publication. SPIE uses a seven-digit CID article numbering system structured as follows: - The first five digits correspond to the SPIE volume number.

- The last two digits indic ate public ation order within the volume using a Base 36 numbering system employing both numerals and letters. These two-number sets start with $00,01,02,03,04$, $05,06,07,08,09,0 A, 0 B \ldots$. 0Z, followed by 10-1Z, 20-2Z, etc. The CID Number appears on each page of the manuscript.
} 


\section{Contents}

\section{UAV REMOTIE SENSING FOR PHENOTYPING IN CROPS}

1174703 Investigate the potential of UAS-based themal infrared imagery for maize leaf area index estimation [11747-1]

$1174704 \quad$ Individual maize extraction from UAS imagery-based point clouds by 3D deep leaming [11747-2]

1174706 Predicting vineyard canopy coverage using drone pictures [11747-4]

THE PAST AND FUIURE OF PRACTICE REMOTE SENSING IN AGRIC ULTURE

11747 OA Lessons leamed towards the immediate delivery of massive aenial imagery to famers and crop consultants [11747-8]

MAXIMIZNG ACCURACY IN UAV REMOTE-SENSING DATA

11747 OD Automated calibration pipeline for agric ultural sUAS based remote sensing [11747-11]

11747 OE A collaborative operation system of autonomous unmanned aenal vehic les for field phenotyping in farm fields [11747-12]

GROUND-BASED AND ROBOTIC SYSTEMS IN AGRIC ULTURALSENSING AND PHENOTYPING

11747 ol Scientific timely actionable robotic data operating system (STARDOS): architecture and progress [11747-16]

UAV REMOTE SENSING FOR MEASURING EVAPOTRANSPIRATION AND MOISTURE FACTORS IN CROPS

11747 0] A UAS-based RF testbed for water utilization in agroecosystems (Keynote Paper) [11747-17]

11747 OK Development of high performance computing tools for estimation of high-resolution surface energy balance products using sUAS information [11747-18] 
$11747 \mathrm{OL}$ Toward accurate estimating of crop leaf stomatal conductance combining themal IR imaging, weather variables, and machine leaming [11747-19]

11747 ON Evapotranspiration partitioning assessment using a machine-leaming-based leafarea index and the two-source energy balance model with sUAV information [11747-21] 